\title{
POLITIK HUKUM KETAHANAN PANGAN NASIONAL (KAJIAN SINKRONISASI POLITIK HUKUM UNDANG-UNDANG HAK PVT DAN UNDANG-UNDANG PANGAN)
}

\author{
oleh: \\ Moch Najib Imanullah \\ Fakultas Hukum Universitas Sebelas Maret \\ E-mail: imanullahnajib@yahoo.com
}

\begin{abstract}
The aim of this research is to determine the level of legal synchronization horizontally on legal policy of national food security within Act on Plant Variety Protection and Act on Food. In order to achieve this aim, it was conducted normative legal research which using secondary data which is based on primary and secondary legal materials. Data were analyzed by using a legal grammatical interpretation. Its results are there is a synchronization between Act on Plant Variety Protection and Act on Food and by the legal protection of plant varieties will increase enthusiasm plant breeders to produce new quality seeds crop, including the food crops seeds. It will lead to increasing national food security conditions, which will provide guarantee on quality and sufficient of food for families who receive it.
\end{abstract}

Keywords: legal policy, crop variety, food, national food security.

\begin{abstract}
Abstrak
Penelitian ini bertujan untuk mengetahui taraf sinkronisasi hukum secara horizontal politik hukum ketahanan pangan nasional dalam Undang-undang Perlindungan Varietas Tanaman dan Undang-undang Pangan. Untuk mencapai tujuan ini maka dilakukan penelitian hukum normatif menggunakan data sekunder yang bersumber pada bahan hukum primer dan sekunder. Data yang diperoleh dianalisis dengan menggunakan penafsiran hukum gramatikal. Dari penelitian ini diperoleh hasil bahwa Undang-undang Perlindungan Varietas Tanaman sinkron dengan Undang-undang Pangan, yaitu adanya perlindungan hukum terhadap Hak Perlindungan Varietas Tanaman akan meningkatkan gairah para pemulia tanaman untuk menghasilkan benih-benih tanaman baru yang berkualitas, termasuk benih-benih tanaman bahan pangan. Tersedianya benih-benih tanaman bahan pangan yang cukup, akan meningkatkan produksi bahan pangan, sehingga akan tercapai kondisi meningkatnya ketahanan pangan nasional, yang menjamin sampai pada tingkat keluarga menerima bahan pangan yang cukup dan bermutu.
\end{abstract}

Kata kunci : politik hukum, varietas tanaman, pangan, ketahanan pangan nasional.

\section{A. Pendahuluan}

Indonesia merupakan salah satu negara yang memiliki sumber daya hayati yang sangat beragam, dan sering dijuluki sebagai negara yang memiliki megabiodiversity. Keanekaragaman ini merupakan sumber plasma nuftah yang dapat dimanfaatkan untuk merakit varietas unggul, yang sangat penting bagi pembangunan sektor pertanian, ketahanan pangan, dan pembangunan perekonomian nasional. Karenanya, pihak yang telah melakukan pemuliaan tanaman harus diberi penghargaan. Salah satu bentuk penghargaan tersebut merupakan memberikan perlindungan hukum Hak Kekayaan Intelektual (HKI) terhadap varietas tanaman yang dihasilkan (Moch Najib Imanullah, 2012:589).

Dengan adanya perlindungan HKI terhadap varietas tanaman ini akan banyak memberikan manfaat, seperti: meningkatkan jumlah dan kecepatan varietas unggul baru yang kompetitif, meningkatkan kompetensi industri perbenihan, membendung membanjirnya produk impor, meningkatkan pendapatan petani, membuka lapangan kerja baru, meningkatkan kajian pemuliaan, meningkatkan produktivitas, meningkatkan kualitas komoditas pertanian, meningkatkan diversitas varietas, mengurangi ketergantungan pada bahan-bahan kimia, dan perluasan pertanian ke lahan-lahan marginal. Perlindungan hukum ini pada hakekatnya sekaligus merupakan pelaksanaan dari berbagai kewajiban internasional yang harus dilaksanakan Indonesia, khususnya yang berkaitan dengan Konvensi Perserikatan Bangsa-bangsa tentang Keanekaragaman Hayati (United Convention on Biological Diversity), Konvensi Internasional tentang Perlindungan Varietas Baru Tanaman (International Convention for the Protection of New Varieties of Plants), dan World Trade Organization/Trade Related Aspect 
of Intellectual Property Rights, yang antara lain mewajibkan kepada negara anggota seperti Indonesia mempunyai dan melaksanakan peraturan perundang-undangan di bidang HKI, termasuk PVT.

Pemberian PVT juga dilaksanakan untuk mendorong dan memberi peluang kepada dunia usaha untuk meningkatkan perananya dalam berbagai aspek pembangunan pertanian. Hal ini semakin penting mengingat perakitan varietas unggul di Indonesia saat ini masih lebih banyak dilakukan oleh lembaga penelitian pemerintah. Pada waktunya yang akan datang diharapkan dunia usaha dapat semakin berperan, sehingga lebih banyak varietas tanaman yang lebih unggul dan lebih beragam dapat dihasilkan.

Keuntungan-keuntungan tersebut akan bermuara pada pencapaian ketahanan pangan nasional. Perlindungan tersebut juga diharapkan akan mendorong kreativitas di bidang pemuliaan tanaman, sehingga dapat menghasilkan penemuan berbagai varietas unggul yang sangat diperlukan masyarakat. Untuk memberikan landasan hukum yang kuat bagi pemberian perlindungan varietas tanaman hasil pemuliaan dan hak-hak pihak yang melakukan pemuliaan, maka diundangkan UndangUndang Nomor 29 tahun 2000 Tentang Perlindungan Varietas Tanaman (UU PVT).

Persoalan perlindungan terhadap varietas tanaman ini penting untuk diteliti karena apabila tidak ada perlindungan yang memadai maka akan timbul ketidak-puasan bagi pemulia, perasaan tidak adil, dan tidak menstimulasi untuk lebih inovatif. Dengan adanya perlindungan $\mathrm{HKI}$, maka akan dirangsang peningkatan karya intelektual yang mampu menghasilkan teknik dan teknologi baru yang akan menggairahkan dunia usaha, termasuk dunia usaha yang bergerak dalam bidang pemuliaan tanaman dan pengadaan benih-benih unggul, termasuk benih-benih unggul tanaman bahan pangan. Badan Pusat Statistik (BPS) merilis data bahwa produksi beras nasional mencapai 37 juta ton, sementara itu kebutuhan diasumsikan 33,5 juta ton. Dengan demikian terjadi surplus. Namun surplus ini bersifat musiman, karena pada waktu tertentu justru terjadi kelangkaan beras sebagai salah satu sumber pangan. Sedangkan jagung yang juga merupakan bahan pangan penting, produksi nasional mencapai 17,93 juta ton pipilan kering. Produksi ini turun 438,96 ribu ton apabila dibandingkan dengan produksi tahun yang lalu. Penyebabnya merupakan penurunan luas lahan panen. Sementara itu, produksi ubi kayu hanya mencapai kisaran 21.756.991 ton dan untuk memenuhi kebutuhan Pemerintah akan mengimpor ubi kayu dari negara lain. Ketidakstabilan produksi bahan pangan tersebut dan bahan pangan lainnya telah memaksa Pemerintah untuk menyiapkan dan Rp. 3 triliyun untuk menjaga stabilitas ketahanan pangan tahun ini (www.bps.go.id, diakses 2 Oktober 2011).

Persoalan kurangnya produk dan berkurangnya luas lahan panen, salah satu alternatif solusinya merupakan apabila tersedia varietas dan bibit unggul yang dapat meningkatkan produktivitas. Salah satu solusi ketersediaan varietas dan bibit yang unggul tersebut merupakan adanya kegairahan pemulia maupun produsen untuk melakukan pemuliaan varietas, dan ini akan mereka lakukan apabila karya mereka dihargai dan dilindungi, antara lain dengan perlindungan HKI melalui pemberian Hak PVT. Akhirnya kondisi yang kondusif ini akan memberikan sumbangan yang cukup signifkan terhadap upaya pencapaian ketahanan pangan nasional.

Permasalahan mendasar saat ini yang perlu dikaji dengan seksama adalah: apakah politik hukum peraturan perundang-undangan di bidang PVT dan Pangan telah sinkron sehingga mampu memberikan sumbangan yang signifikan mencapai ketahanan pangan nasional.

\section{B. Metode Penelitian}

Penelitian ini merupakan penelitian hukum normatif, yaitu penelitian taraf sinkronisasi horizontal antara Undang-undang PVT dengan Undangundang Pangan, untuk mengungkapkan keserasiannya (Soerjono Soekanto dan Sri Mamudji, 2007: 74). Penelitian ini menggunakan data sekunder berupa bahan hukum primer yang bersumber dari kedua undang-undang tersebut. Selain itu, penelitian ini juga menggunakan bahan hukum primer yang bersumber pada jurnal-jurnal hasil penelitian yang mengkaji Hak PVT dan ketahanan pangan nasional. Kesahihan data diperoleh dengan melakukan kritik sumber. Adapun analisisnya menggunakan penafsiran hukum gramatikal.

\section{Hasil Penelitian dan Pembahasan \\ 1. Politik Hukum}

Politik hukum secara singkat berarti kebijaksanaan hukum (Imam Syaukani dan A. Ahsin Thohari, 2007: 25). Sementara itu Satjipto Rahardjo mengemukakan beberapa pertanyaan mendasar mengenai studi politik hukum, yaitu : (1) tujuan apa yang hendak dicapai dengan sistem hukum yang ada; (2) cara-cara apa dan yang mana, yang dirasa paling baik untuk bisa dipakai mencapai tujuan tersebut; (3) kapan waktunya hukum itu perlu diubah melalui cara-carabagaimana perubahan itu dilakukan; (4) dapatkah dirumuskan suatu pola yang baku dan mapan yang bisa 
membantu memutuskan proses pemilihan tujuan serta cara-cara untuk mencapai tujuan tersebut secara baik. Satjipto Rahardjo memberikan pengertian politik hukum sebagai aktivitas memilih dan cara yang hendak dipakai untuk mencapai suatu tujuan sosial dan hukum tertentu dalam masyarakat (Satjipto Rahardjo, 1991: 352).

Dalam bukunya yang berjudul Politik Hukum di Indonesia, Moh. Mahfud MD mengemukakan bahwa ternyata hukum tidak steril dari sub sistem kemasyarakatan lainnya. Politik kerap kali melakukan intervensi atas pembuatan dan pelaksanaan hukum sehingga muncul juga pertanyaan berikutnya tentang subsistem mana antara hukum dan politik yang dalam kenyataannya lebih suprematif. Politik hukum, secara sederahana dapat dirumuskan sebagai kebijaksanaan hukum (legal policy) yang akan atau telah dilaksanakan secara nasional oleh Pemerintah; mencakup pula pengertian tentang bagaimana politik mempengaruhi hukum dengan cara melihat konfigurasi kekuatan yang ada di belakang pembuatan dan penegakan hukum (Moh. Mahfud MD,2006:1-2).

\section{Perlindungan Varietas Tanaman}

Sebuah varietas tanaman dapat diberi Hak PVT apabila berasal dari jenis atau spesies tanaman yang baru, unik, seragam, stabil, dan diberi nama. Suatu varietas dianggap baru apabila pada saat penerimaaan permohonan Hak PVT, bahan perbanyakan atau hasil panen dari varietas tersebut belum pernah diperdagangkan di Indonesia atau sudah diperdagangkan tetapi tidak lebih dari setahun, atau telah diperdagangkan di luar negeri tidak lebih dari empat tahun untuk tanaman semusim dan enam tahun untuk tanaman tahunan.

Suatu varietas dianggap unik, apabila varietas tersebut dapat dibedakan secara jelas dengan varietas lain yang keberadaannya sudah diketahui secara umum pada saat penerimaan permohonan Hak PVT. Suatu varietas dianggap seragam, apabila sifat-sifat utama atau penting pada varietas tersebut terbukti seragam meskipun bervariasi sebagai akibat dari cara tanam dan lingkungan yang berbeda-beda. Suatu varietas dianggap stabil, apabila sifat-sifatnya tidak mengalami perubahan setelah ditanam berulang-ulang, atau untuk yang diperbanyak melalui siklus perbanyakan khusus tidak mengalami perubahan pada setiap akhir siklus tersebut (Pasal 2 Undang-undang Nomor 29 Tahun 2009
Tentang PVT). Sedangkan varietas tanaman yang tidak dapat diberikan perlindungan Hak Varietas Tanaman meliputi: varietas yang penggunaannya bertentangan dengan peraturan perundang-undangan yang berlaku, ketertiban umum, kesusilaan, norma-norma agama, kesehatan, dan kelestarian lingkungan hidup. Hak PVT ini diberikan selama 20 tahun untuk tanaman semusim, 25 tahun untuk tanaman tahunan.

Implikasi dari pemberian Hak PVT, pemegang Hak PVT memiliki hak untuk menggunakan dan memberikan persetujuan kepada orang atau badan hukum lain untuk menggunakan varietas berupa benih dan hasil panen yang digunakan untuk propagasi. Selain hak tersebut, pemegang Hak PVT juga dibebani kewajiban, yaitu: melaksanakan hak PVT-nya di Indonesia, membayar biaya tahunan Hak PVT, menyediakan dan menunjukkan contoh benih varietas yang telah mendapatkan Hak PVT di Indonesia. Hak PVT tidak bersifat mutlak, dalam pengertian ada perbuatan atau tindakan tertentu yang apabila dilakukan, oleh Undang-Undang PVT tidak dianggap sebagai pelanggaran Hak PVT, yaitu: (a) penggunaan sebagian hasil panen dari varietas yang dilindungi sepanjang tidak untuk tujuan komersial; (b) penggunaan varietas yang dilindungi untuk kegiatan kajian, pemuliaan tanaman, dan perakitan varietas baru; (c) penggunaan varietas yang dilindungi oleh Pemerintah dalam rangka kebijakan pengadaan pangan dan obat-obatan dengan memperhatikan hak-hak ekonomi dari pemegang Hak PVT.

Maksud dari pemuliaan tanaman merupakan mengembangkan varietas yang lebih baik dari yang sudah ada. Meskipun demikian keuntungan dari varietas baru tersebut belum dapat dirasakan, sebelum tersedia benih yang cukup untuk penanaman skala komersial di daerah yang cocok. Demikian pula dengan penyebaran benih ke petani belum tentu menyelesaikan masalah dalam pemanfaatan varietas baru, kecuali dibuat aturan-aturan untuk mempertahankan varietas. Apabila kendala-kendala tersebut dapat diatasi, khususnya penciptaan iklim kondusif melalui pemutakhiran peraturan perundang-undangan di bidang PVT, budi-daya tanaman, pangan, dan ketahanan pangan, maka kegairahan untuk merakit varietas baru akan semakin meningkat, tingkat produksi dan keanekaragaman tanaman pangan meningkat, sehinggta pada akhirnya dapat memberikan sumbangan yang 
signifikan kepada ketahanan pangan nasional, dan meningkatkan daya saing produk tanaman pangan nasional di pasar internasional.

Untuk sampai pada kondisi tersebut, perlu untuk melakukan kajian-kajian yang dapat dijadikan dasar pijakan dalam penyusunan kebijakan penggunaan PVT sebagai salah satu instrumen penting untuk mencapai ketahanan pangan nasional. Adapun kajian-kajian yang dimaksud meliputi : (a) identifikasi, inventarisasi, dan pemetaan plasma nuftah yang dapat dimanfaatkan untuk merakit varietas unggul tanaman pangan yang dimintakan perlindungan Hak PVT; (b) identifikasi dan inventarisasi permasalahan yang dihadapi pemohon untuk memperoleh Hak PVT; (c) identifikasi dan inventarisasi upaya-upaya yang telah dilakukan Pemerintah dan pemangku kepentingan untuk meningkatkan perolehan Hak PVT; (d) mengidentifikasi dan mengkaji taraf sinkronisisasi hukum, vertikal maupun horizontal, yang mengatur Hak PVT, pangan dan ketahanan pangan nasional (e) mengidentifikasi dan mengkaji pemutakhiran peraturan perundang-undangan yang mengatur PVT dan pangan dalam rangka menuju ketahanan pangan nasional. Setelah kajiankajian tersebut dilakukan dengan cukup seksama, maka pada akhirnya dilakukan kajian: pengaruh pemberian Hak PVT terhadap peningkatan ketahanan pangan nasional.

\section{Ketahanan Pangan Nasional}

Kebutuhan pangan nasional terus meningkat sejalan dengan pertumbuhan penduduk, sehingga mengaharuskan produksi pertanian untuk terus ditingkatkan. Berbagai upaya terus dilakukan termasuk kebijakan ketahanan pangan berbasis sumber daya lokal. Secara normatif, untuk dapat mewujudkan ketahanan pangan sumber utama pasokan pangan harus dapat diproduksi sendiri hingga ke tingkat rumah tangga (E.S. Beramang, 2012: 325). Sementara itu, sektor pertanian sebagai tumpuan utama dalam memenuhi kebutuhan pangan nasional kini kondisinya semakin terpuruk. Hal ini dapat dilihat dari semakin meningkatnya jumlah penduduk yang berarti pula semakin meningkatnya jumlah kebutuhan pangan nasional, sedangkan sektor pertanian semakin terpuruk sebagai akibat semakin rendahnya daya dukung lingkungan. Oleh karena itu, paradigma pembangunan pertanian dalam rangka ketahanan pangan nasional lebih dititikberatkan pada pertanian berkelanjutan yang berwawasan lingkungan dan lebih memusatkan pada keanekaragaman sumber pangan (Emi Widayanti, 2012: 363).

Selain persoalan jumlah penduduk yang semakin meningkat, persoalan kecukupan pangan dalam rangka ketahanan pangan nasional salah satu diantaranya adalah semakin berkurangnya lahan pertanian karena alih fungsi, menjadi daerah perindustrian, perumahan, dan kebutuhan lahan lainnya. Salah satu alternatif solusinya adalah pengembangan wanatani. Dalam wanatani, hutan dikelola untuk kegiatan pertanian oleh masyarakat atau petani di sekitar hutan tanpa merusak fungsi hutan, bahkan kegiatan produktif ini diharapkan juga meningkatkan kelestarian hutan. Dengan demikian, hutan dengan wanataninya akan membuka peluang terwujudnya kedaulatan pangan berbasis utama pada kearifan lokal dan sumber daya lokal (Yudi Widodo, 2012: 332). Selain program wanatani, persoalan produksi pangan karena berkurangnya lahan juga dapat diatasi dengan penggunaan bibit-bibit unggul dengan produktivitas tinggi. Namun demikian, dalam penerapan budidaya petani masih mengalami masalah teknis berupa ketersediaan bibit unggul yang tidak tepat waktu (Ade Ruskandar, 2012: 287). Di sini terlihat, bahwa kegiatan pemuliaan tanaman untuk menghasilkan bibit unggul mempunyai peran penting dalam rangka ketahanan pangan nasional. Oleh karena itu, pemberian dan perlindungan Hak PVT kepada pemulia tanaman sangat layak untuk diberikan, sehingga ada kegairahan untuk merakit bibibibit unggul yang akan mampu meningkatkan produktivitas bahan pangan.

\section{Politik Hukum Undang-Undang PVT}

Negara Republik Indonesia merupakan negara agraris, maka pertanian yang maju, efisien, dan tangguh mempunyai peranan yang penting dalam rangka pencapaian tujuan pembangunan nasional. Untuk membangun pertanian yang maju, efisien, dan tangguh perlu didukung dan ditunjang antara lain dengan tersedianya varietas unggul. Indonesia sangat kaya sumberdaya plasma nutfah yang merupakan bahan utama pemuliaan tanaman, perlu dilestarikan dan dimanfaatkan sebaikbaiknya dalam rangka merakit dan mendapatkan varietas unggul tanaman tanpa merugikan pihak manapun yang terkait guna mendorong pertumbuhan industri perbenihan. 
Guna lebih meningkatkan minat dan peranserta perorangan maupun badan hukum untuk melakukan kegiatan pemuliaan tanaman dalam rangka menghasilkan varietas unggul baru, kepada pemulia tanaman atau pemegang hak Perlindungan Varietas Tanaman perlu diberikan hak tertentu serta perlindungan hukum atas hak tersebut secara memadai.

Perlindungan Varietas Tanaman yang selanjutnya disingkat PVT, adalah perlindungan khusus yang diberikan negara, yang dalam hal ini diwakili oleh Pemerintah dan pelaksanaannya dilakukan oleh Kantor Perlindungan Varietas Tanaman, terhadap varietas tanaman yang dihasilkan oleh pemulia tanaman melalui kegiatan pemuliaan tanaman. Adapun Hak Perlindungan Varietas Tanaman adalah hak khusus yang diberikan negara kepada pemulia dan/atau pemegang hak Perlindungan Varietas Tanaman untuk menggunakan sendiri varietas hasil pemuliaannya atau memberi persetujuan kepada orang atau badan hukum lain untuk menggunakannya selama waktu tertentu.

Pemegang hak PVT memiliki hak untuk menggunakan dan memberikan persetujuan kepada orang atau badan hukum lain untuk menggunakan varietas berupa benih dan hasil panen yang digunakan untuk propagasi. Ketentuan ini berlaku juga untuk:

a. Varietas turunan esensial yang berasal dari suatu varietas yang dilindungi atau varietas yang telah terdaftar dan diberi nama;

b. Varietas yang tidak dapat dibedakan secara jelas;

c. Varietas yang diproduksi dengan selalu menggunakan varietas yang dilindungi.

Hak untuk menggunakan varietas tersebut meliputi kegiatan: memproduksi atau memperbanyak benih; menyiapkan untuk tujuan propagasi; mengiklankan; menawarkan; menjual atau memperdagangkan; mengekspor; mengimpor; mencadangkan untuk keperluan tersebut. Penggunaan hasil panen yang digunakan untuk propagasi yang berasal dari varietas yang dilindungi, harus mendapat persetujuan dari pemegang hak PVT. Penggunaan varietas turunan esensial harus mendapat persetujuan dari pemegang hak PVT dan/atau pemilik varietas asal dengan ketentuan sebagai berikut.

a. Varietas turunan esensial berasal dari varietas yang telah mendapat hak PVT atau mendapat penamaan berdasarkan peraturan perundang-undangan yang berlaku dan bukan merupakan varietas turunan esensial sebelumnya;

b. Varietas tersebut pada dasarnya mempertahankan ekspresi sifat-sifat esensial dari varietas asal, tetapi dapat dibedakan secara jelas dengan varietas asal dari sifat-sifat yang timbul dari tindakan penurunan itu sendiri;

c. Varietas turunan esensial tersebut (butir a dan butir b) dapat diperoleh dari mutasi alami atau mutasi induksi, variasi somaklonal, seleksi individu tanaman, silang balik, dan transformasi dengan rekayasa genetika dari varietas asal.

Varietas asal untuk menghasilkan varietas turunan esensial harus telah diberi nama dan didaftar oleh Pemerintah. Sementara itu varietas lokal milik masyarakat dikuasai oleh Negara. Penguasaan oleh Negara tersebut dilaksanakan oleh Pemerintah, yang berkewajiban memberikan penamaan terhadap varietas lokal tersebut. Pemulia yang menghasilkan varietas berhak untuk mendapatkan imbalan yang layak dengan memperhatikan manfaat ekonomi yang dapat diperoleh dari varietas tersebut. Imbalan tersebut dapat dibayarkan dengan cara sebagai berikut.

a. Dalam jumlah tertentu dan sekaligus;

b. Berdasarkan persentase;

c. Dalam bentuk gabungan antara jumlah tertentu dan sekaligus dengan hadiah atau bonus;

d. Dalam bentuk gabungan antara persentase dengan hadiah atau bonus, yang besarnya ditetapkan sendiri oleh pihakpihak yang bersangkutan.

Ketentuan tersebut sama sekali tidak menghapuskan hak pemulia untuk tetap dicantumkan namanya dalam sertifikat pemberian hak PVT. Seiring dengan pemberian Hak PVT, maka sebagai imbangannya Pemegang hak PVT berkewajiban sebagai berikut.

a. Melaksanakan hak PVT-nya di Indonesia;

b. Membayar biaya tahunan PVT;

c. Menyediakan dan menunjukkan contoh benih varietas yang telah mendapatkan hak PVT di Indonesia.

Dikecualikan dari kewajiban tersebut apabila pelaksanaan PVT tersebut secara teknis dan/atau ekonomis tidak layak dilaksanakan di Indonesia. Pengecualian ini hanya dapat disetujui Kantor PVT apabila 
diajukan permohonan tertulis oleh pemegang hak PVT dengan disertai alasan dan bukti-bukti yang diberikan oleh instansi yang berwenang. Sering ada opini sebagian masyarakat, bahwa pemberian Hak PVT ini juga akan merugikan kepentingan yang lebih luas, yaitu adanya kriminalisasi atau sanksi terhadap pelanggraran Hak PVT. Pendapat ini tidak benar, karena UU PVT telah mengatur pengecualian-pengecualian sehingga beberapa kegiatan yang dikhawatirkan sebagai pelanggaran, tidak dianggap sebagai pelanggaran Hak PVT, yaitu apabila :

a. Penggunaan sebagian hasil panen dari varietas yang dilindungi, sepanjang tidak untuk tujuan komersial;

b. Penggunaan varietas yang dilindungi untuk kegiatan penelitian, pemuliaan tanaman, dan perakitan varietas baru;

c. Penggunaan oleh Pemerintah atas varietas yang dilindungi dalam rangka kebijakan pengadaan pangan dan obatobatan dengan memperhatikan hak-hak ekonomi dari pemegang hak PVT.

Ketentuan tersebut, merupakan politik hukum UU PVT dalam rangka mendukung upaya-upaya pencapaian ketahanan pangan nasional. Politik hukum UU PVT dalam rangka mengarahkan pengaturan pemberian perlindungan Hak PVT juga tampak dari ketentuan mengenai pemebrian Lisensi Wajib, yang mengatur sebagai berikut.

a. Setiap orang atau badan hukum, setelah lewat jangka waktu 36 (tiga puluh enam) bulan terhitung sejak tanggal pemberian hak PVT, dapat mengajukan permintaan Lisensi Wajib kepada Pengadilan Negeri untuk menggunakan hak PVT yang bersangkutan.

b. Permohonan Lisensi Wajib hanya dapat dilakukan dengan alasan bahwa: hak PVT yang bersangkutan tidak digunakan di Indonesia:

c. Hak PVT telah digunakan dalam bentuk dan cara yang merugikan kepentingan masyarakat.

Lisensi Wajib merupakan lisensi untuk melaksanakan suatu hak PVT yang diberikan oleh Pengadilan Negeri setelah mendengar konfirmasi dari pemegang hak PVT yang bersangkutan dan bersifat terbuka. Lisensi Wajib hanya dapat diberikan apabila:

a. Pemohon dapat menunjukkan bukti yang meyakinkan bahwa yang bersangkutan mempunyai kemampuan dan fasilitas untuk menggunakan sendiri hak PVT tersebut serta telah berusaha mengambil langkah-langkah untuk mendapatkan lisensi dari pemegang Hak PVT atas dasar persyaratan dan kondisi yang wajar, tetapi tidak berhasil.

b. Pengadilan Negeri menilai bahwa hak PVT tersebut dapat dilaksanakan di Indonesia dan bermanfaat bagi masyarakat.

Pemeriksaan atas permohonan Lisensi Wajib dilakukan oleh Pengadilan Negeri dalam suatu persidangan dengan mendengarkan pendapat tenaga ahli dari Kantor PVT dan pemegang hak PVT yang bersangkutan. Lisensi Wajib ini diberikan untuk jangka waktu yang tidak lebih lama dari hak PVT. Apabila berdasarkan bukti serta pendapat dan Pengadilan Negeri memperoleh keyakinan bahwa belum cukup jangka waktu bagi pemegang hak PVT untuk menggunakannya secara komersial di Indonesia, maka Pengadilan Negeri dapat menetapkan penundaan untuk sementara waktu proses persidangan tersebut atau menolaknya.

Pelaksanaan Lisensi Wajib disertai dengan pembayaran royalti oleh pemegang Lisensi Wajib kepada pemegang hak PVT. Besarnya royalti yang harus dibayarkan dan tata cara pembayarannya ditetapkan Pengadilan Negeri. Penetapan besarnya royalti dilakukan dengan memperhatikan tata cara yang lazim digunakan dalam perjanjian lisensi PVT atau perjanjian lain yang sejenis. Dalam putusan Pengadilan Negeri mengenai pemberian Lisensi Wajib dicantumkan hal-hal sebagai berikut.

a. Alasan pemberian Lisensi Wajib;

b. Bukti termasuk keterangan atau penjelasan yang diyakini untuk dijadikan dasar pemberian Lisensi Wajib;

c. Jangka waktu Lisensi Wajib;

d. Besarnya royalti yang harus dibayarkan pemegang Lisensi Wajib kepada pemegang Hak PVT dan tata cara pembayarannya;

e. Syarat berakhirnya Lisensi Wajib dan hal yang dapat membatalkannya;

f. Lisensi Wajib semata-mata digunakan untuk memenuhi kebutuhan pasar di dalam negeri;

g. Lain-lain yang diperlukan untuk menjaga kepentingan pihak yang bersangkutan secara adil. 
Pemegang Lisensi Wajib berkewajiban mencatatkan Lisensi Wajib yang diterimanya pada Kantor PVT dan dicatat dalam Daftar Umum PVT. Lisensi Wajib yang telah dicatatkan, secepatnya diumumkan oleh Kantor PVT dalam Berita Resmi PVT. Lisensi Wajib baru dapat dilaksanakan setelah dicatatkan dalam Daftar Umum PVT dan pemegangnya telah membayar royalti. Pelaksanaan Lisensi Wajib dianggap sebagai pelaksanaan hak PVT. Lisensi Wajib berakhir karena alasan-alasan sebagai berikut.

a. Selesainya jangka waktu yang ditetapkan dalam pemberiannya;

b. Dibatalkan atau dalam hal pemegang Lisensi Wajib menyerahkan kembali lisensi yang diperolehnya kepada Kantor PVT sebelum jangka waktu tersebut berakhir

Kantor PVT mencatat Lisensi Wajib yang telah berakhir jangka waktunya dalam buku Daftar Umum PVT, mengumumkan dalam Berita Resmi PVT, dan memberitahukannya secara tertulis kepada pemegang hak PVT serta Pengadilan Negeri yang memutuskan pemberiannya. Batal atau berakhirnya Lisensi Wajib berakibat pulihnya pemegang hak PVT atas hak PVT yang bersangkutan.

\section{Politik Hukum Undang-undang Pangan}

Politik hukum ketahanan pangan nasional dapat dicermati dari konsideran Undangundang Pangan, yang mengarahkan bahwa pangan merupakan kebutuhan dasar manusia yang pemenuhannya menjadi hak asasi setiap rakyat Indonesia dalam mewujudkan sumber daya manusia yang berkualitas untuk melaksanakan pembangunan nasional. Pangan yang aman, bermutu, bergizi, beragam, dan tersedia secara cukup merupakan prasyarat utama yang harus dipenuhi dalam upaya terselenggaranya suatu sistem pangan yang memberikan perlindungan bagi kepentingan kesehatan serta makin berperan dalam meningkatkan kemakmuran dan kesejahteraan rakyat. Pangan sebagai komoditas dagang memerlukan dukungan sistem perdagangan pangan yang jujur dan bertanggung jawab sehingga tersedia pangan yang terjangkau oleh daya beli masyarakat serta turut berperan dalam peningkatan pertumbuhan ekonomi nasional.

Pangan merupakan segala sesuatu yang berasal dari sumber hayati dan air, baik yang diolah maupun tidak diolah, yang diperuntukkan sebagai makanan atau minuman bagi konsumsi manusia, termasuk bahan tambahan pangan, bahan baku pangan, dan bahan lain yang digunakan dalam proses penyiapan, pengolahan, dan atau pembuatan makanan atau minuman. Adapun sistem pangan merupakan segala sesuatu yang berhubungan dengan pengaturan, pembinaan, dan atau pengawasan terhadap kegiatan atau proses produksi pangan dan peredaran pangan sampai dengan siap dikonsumsi manusia. Sementara itu, keamanan pangan merupakan kondisi dan upaya yang diperlukan untuk mencegah pangan dari kemungkinan cemaran biologis, kimia, dan benda lain yang dapat mengganggu, merugikan, dan membahayakan kesehatan manusia. Salah satu kata kunci dalam ketahanan pangan nasional adalah produksi pangan yang merupakan kegiatan atau proses menghasilkan, menyiapkan, mengolah, membuat, mengawetkan, mengemas, mengemas kembali, dan atau mengubah bentuk pangan.

Untuk mencapai ketahanan pangan, sektor pengangkutan pangan merupakan setiap kegiatan atau serangkaian kegiatan dalam rangka memindahkan pangan dari satu tempat ke tempat lain dengan cara atau sarana angkutan apa pun dalam rangka produksi, peredaran, dan atau perdagangan pangan. Pengangkutan pangan yang baik, akan menjamin peredaran pangan sampai pada wilayah-wilayah Indonesia yang mengalami kekurangan pangan. Peredaran pangan merupakan setiap kegiatan atau serangkaian kegiatan dalam rangka penyaluran pangan kepada masyarakat, baik untuk diperdagangkan maupun tidak. Sedangkan perdagangan pangan merupakan setiap kegiatan atau serangkaian kegiatan dalam rangka penjualan dan atau pembelian pangan, termasuk penawaran untuk menjual pangan, dan kegiatan lain yang berkenaan dengan pemindahtanganan pangan dengan memperoleh imbalan.

Ketahanan pangan nasional mengarah pada kondisi masyarakat memperoleh mutu pangan yang baik, merupakan nilai yang ditentukan atas dasar kriteria keamanan pangan, kandungan gizi, dan standar perdagangan terhadap bahan makanan, makanan, dan minuman. Pada akhirnya, akan tercapai ketahanan pangan nasional yang merupakan kondisi terpenuhinya pangan bagi rumah tangga yang tercermin dari tersedianya pangan yang cukup, baik jumlah maupun 
mutunya, aman, merata, dan terjangkau. Pembangunan pangan diselenggarakan untuk memenuhi kebutuhan dasar manusia yang memberikan manfaat secara adil dan merata berdasarkan kemandirian dan tidak bertentangan dengan keyakinan masyarakat. Tujuan pengaturan, pembinaan, dan pengawasan pangan merupakan:

a. Tersedianya pangan yang memenuhi persyaratan keamanan, mutu, dan gizi bagi kepentingan kesehatan manusia;

b. Terciptanya perdagangan pangan yang jujur dan bertanggung jawab;

c. Terwujudnya tingkat kecukupan pangan dengan harga yang wajar dan terjangkau sesuai dengan kebutuhan masyarakat.

Salah satu aspek yang pengting untuk diperhatikan dalam membangun ketahanan pangan nasional adalah persoalan keamanan pangan. Sanitasi Pangan, yang diatur sebagai berikut.

a. Pemerintah menetapkan persyaratan sanitasi dalam kegiatan atau proses produksi, penyimpanan, pengangkutan, dan atau per-edaran pangan.

b. Persyaratan tersebut merupakan persyaratan minimal yang wajib dipenuhi dan ditetapkan serta diterapkan secara bertahap dengan memperhatikan kesiapan dan kebutuhan sistem pangan.

c. Sarana dan atau prasarana yang digunakan secara langsung atau tidak langsung dalam kegiatan atau proses produksi, penyimpanan, pengangkutan, dan atau peredaran pangan wajib memenuhi persyaratan sanitasi.

d. Penyelenggaraan kegiatan atau proses produksi, penyimpanan, pengangkutan, dan atau peredaran pangan serta penggunaan sarana dan prasarana, dilakukan sesuai dengan persyaratan sanitasi.

e. Setiap orang yang bertanggung jawab dalam penyelenggaraan kegiatan atau proses produksi, penyimpanan, pengangkutan, dan atau peredaran pangan wajib:

1) memenuhi persyaratan sanitasi, keamanan, dan atau keselamatan manusia;

2) menyelenggarakan program pemantauan sanitasi secara berkala; dan

3) menyelenggarakan pengawasan atas pemenuhan persyaratan sanitasi.
Orang perseorangan yang menangani secara langsung dan atau berada langsung dalam lingkungan kegiatan atau proses produksi, penyimpanan, pengangkutan, dan atau peredaran pangan wajib memenuhi persyaratan sanitasi Setiap orang dilarang menyelenggarakan kegiatan atau proses produksi, penyimpanan, pengangkutan, dan atau peredaran pangan dalam keadaan yang tidak memenuhi persyaratan sanitasi.

Berkaitan dengan kegiatan mengedarkan bahan pangan, diatur bahwa setiap orang yang memproduksi pangan untuk diedarkan dilarang menggunakan bahan apa pun sebagai kemasan pangan yang dinyatakan terlarang dan atau yang dapat melepaskan cemaran yang merugikan atau membahayakan kesehatan manusia. Pengemasan pangan yang diedarkan dilakukan melalui tata cara yang dapat menghindarkan terjadinya kerusakan dan atau pencemaran. Pemerintah menetapkan bahan yang dilarang digunakan sebagai kemasan pangan dan tata cara pengemasan pangan tertentu yang diperdagangkan. Bahan yang akan digunakan sebagai kemasan pangan, tetapi belum diketahui dampaknya bagi kesehatan manusia, wajib terlebih dahulu diperiksa keamanannya, dan penggunaannya bagi pangan yang diedarkan dilakukan setelah memperoleh persetujuan Pemerintah. Lebih lanjut, dalam rangka keamanan pangan, maka setiap orang dilarang membuka kemasan akhir pangan untuk dikemaskembali dan diperdagangkan. Ketentuan ini tidak berlaku terhadap pangan yang pengadaannya dalam jumlah besar dan lazim dikemas kembali dalam jumlah kecil untuk diperdagangkan lebih lanjut.

Dalam Undang-undang Pangan, masyarakat berhak memperoleh pangan dengan mutu yang baik, dalam pengertian masyarakat tidak menerima pangan tercemar. Oleh karena itu diatur bahwa setiap orang dilarang mengedarkan:

a. Pangan yang mengandung bahan beracun, berbahaya, atau yang dapat merugikan atau membahayakan kesehatan atau jiwa manusia;

b. Pangan yang mengandung cemaran yang melampaui ambang batas maksimal yang ditetapkan;

c. Pangan yang mengandung bahan yang dilarang digunakan dalam kegiatan atau proses produksi pangan; 
d. Pangan yang mengandung bahan yang kotor, busuk, tengik, terurai, atau mengandung bahan nabati atau hewani yang berpenyakit atau berasal dari bangkai sehingga menjadikan pangan tidak layak dikonsumsi manusia;

e. Pangan yang sudah kedaluwarsa.

Untuk mengawasi dan mencegah tercemarnya pangan, maka Pemerintah:

a. Menetapkan bahan yang dilarang digunakan dalam kegiatan atau proses produksi pangan serta ambang batas maksimal cemaran yang diperbolehkan;

b. Mengatur dan atau menetapkan persyaratan bagi penggunaan cara, metode, dan atau bahan tertentu dalam kegiatan atau proses produksi, pengolahan, penyimpanan, pengangkutan, dan atau peredaran pangan yang dapat memiliki risiko yang merugikan dan atau membahayakan kesehatan manusia;

c. Menetapkan bahan yang dilarang digunakan dalam memproduksi peralatan pengolahan, penyiapan, pemasaran, dan atau penyajian pangan.

Dalam rangka melindungi dan memastikan bahwa pangan yang diterima masyarakat merupakan pangan yang bermutu, maka Pemerintah menetapkan standar mutu pangan. Terhadap pangan tertentu yang diperdagangkan, Pemerintah dapat memberlakukan dan mewajibkan pemenuhan standar mutu pangan yang ditetapkan. Lebih lanjut Pemerintah menetapkan persyaratan sertifikasi mutu pangan yang diperdagangkan. Persyaratan sertifikasi mutu pangan tersebut, diterapkan secara bertahap berdasarkan jenis pangan dengan memperhatikan kesiapan dan kebutuhan sistem pangan. Oleh karena itu, gangkan:

Maka setiap orang dilarang memperda-

a. Pangan tertentu, apabila tidak memenuhi standar mutu yang ditetapkan sesuai dengan peruntukannya;

b. Pangan yang mutunya berbeda atau tidak sama dengan mutu pangan yang dijanjikan;

c. Pangan yang tidak memenuhi persyaratan sertifikasi mutu pangan.

Selain menentukan mutu pangan, Pemerintah juga menetapkan dan menyelenggarakan kebijakan di bidang gizi bagi perbaikan status gizi masyarakat. Untuk meningkatkan kandungan gizi pangan olahan tertentu yang diperdagangkan, Pemerintah dapat menetapkan persyaratan khusus mengenai komposisi pangan. Dalam hal terjadi kekurangan dan atau penurunan status gizi masyarakat, Pemerintah dapat menetapkan persyaratan bagi perbaikan atau pengayaan gizi pangan tertentu yang diedarkan. Setiap orang yang memproduksi pangan, sebagaimana dimaksud pada wajib memenuhi persyaratan tentang gizi yang ditetapkan. Ketahanan pangan nasional juga diupayakan dengan cara mengatur pemasukan dan pengeluaran pangan ke dalam dan dari wilayah Indonesia, agar terjadi kecukupan pangan di Indonesia dan memberikan nilai tambah bagi komoditas pangan Indonesia. Setiap pangan yang dimasukkan ke dalam wilayah Indonesia untuk diedarkan wajib memenuhi ketentuan sebagaimana dimaksud dalam Undang-undang Pangan dan peraturan pelaksanaannya. Setiap orang dilarang memasukkan pangan ke dalam wilayah Indonesia dan atau mengedarkan di dalam wilayah Indonesia pangan yang dimasukkan ke dalam wilayah Indonesia apabila pangan tersebut tidak memenuhi ketentuan Undang-undang Pangan. Terhadap pangan yang dimasukkan ke dalam wilayah Indonesia, Pemerintah dapat menetapkan persyaratan sebagai berikut.

a. Pangan telah diuji dan atau diperiksa serta dinyatakan lulus dari segi keamanan, mutu, dan atau gizi oleh instansi yang berwenang di negara asal;

b. Pangan dilengkapi dengan dokumen hasil pengujian dan atau pemeriksaan;

c. Pangan terlebih dahulu diuji dan atau diperiksa di Indonesia dari segi keamanan, mutu, dan atau gizi sebelum peredarannya.

Lebih lanjut diatur bahwa, setiap orang yang memasukkan pangan ke dalam wilayah Indonesia untuk diedarkan bertanggung jawab atas keamanan, mutu, dan gizi pangan. Untuk pengeluaran pangan ke luar wilayah Indonesia, maka Pemerintah dapat menetapkan persyaratan agar pangan yang dikeluarkan dari wilayah Indonesia untuk diedarkan terlebih dahulu diuji dan atau diperiksa dari segi keamanan, mutu, persyaratan label, dan atau gizi pangan.

Pencapaian ketahanan pangan nasional tidak hanya menjadi tanggung jawab Pemerintah, tetapi juga menjadi tanggung jawab industri pangan dan masyarakat. Badan 
usaha yang memproduksi pangan olahan untuk diedarkan dan atau orang perseorangan dalam badan usaha yang diberi tanggung jawab terhadap jalannya usaha tersebut bertanggung jawab atas keamanan pangan yang diproduksinya terhadap kesehatan orang lain yang mengkonsumsi pangan tersebut. Telah dikemukakan bahwa Pemerintah bersama masyarakat bertanggung jawab untuk mewujudkan ketahanan pangan. Dalam rangka mewujudkan ketahanan pangan, Pemerintah menyelenggarakan pengaturan, pembinaan, pengendalian, dan pengawasan terhadap ketersediaan pangan yang cukup, baik jumlah maupun mutunya, aman, bergizi, beragam, merata, dan terjangkau oleh daya beli masyarakat. Dalam pelaksanaan ketentuan tersebut, maka Pemerintah:

a. Menyelenggarakan, membina, dan atau mengkoordinasikan segala upaya atau kegiatan untuk mewujudkan cadangan pangan nasional;

b. Menyelenggarakan, mengatur, dan atau mengkoordinasikan segala upaya atau kegiatan dalam rangka penyediaan, pengadaan, dan atau penyaluran pangan tertentu yang bersifat pokok;

c. Menetapkan dan menyelenggarakan kebijakan mutu pangan nasional dan penganekaragaman pangan;

d. Mengambil tindakan yang diperlukan untuk mencegah dan atau menanggulangi gejala kekurangan pangan, keadaan darurat, dan atau spekulasi atau manipulasi dalam pengadaan dan peredaran pangan.

Cadangan pangan nasional tersebut, terdiri atas: cadangan pangan Pemerintah dan cadangan pangan masyarakat. Cadangan pangan Pemerintah ditetapkan secara berkala dengan memperhitungkan tingkat kebutuhan nyata pangan masyarakat dan ketersediaan pangan, serta dengan mengantisipasi terjadinya kekurangan pangan dan atau keadaan darurat.

Dalam upaya mewujudkan cadangan pangan nasional, maka Pemerintah:

a. Mengembangkan, membina, dan atau membantu penyelenggaraan cadangan pangan masyarakat dan Pemerintah di tingkat perdesaan, perkotaan, propinsi, dan nasional;

b. Mengembangkan, menunjang, dan memberikan kesempatan seluas-luasnya bagi peran koperasi dan swasta dalam mewujudkan cadangan pangan setempat dan atau nasional.
Dalam mencapai ketahanan pangan nasional, masyarakat memiliki kesempatan untuk berperan seluas-luasnya dalam mewujudkan perlindungan bagi orang perseorangan yang mengkonsumsi pangan, sesuai dengan ketentuan Undang-undang Pangan dan peraturan pelaksanaannya serta peraturan perundang-undangan lain yang berlaku. Dalam rangka penyempurnaan dan peningkatan sistem pangan, masyarakat dapat menyampaikan permasalahan, masukan, dan atau cara pemecahan mengenai hal-hal di bidang pangan.

Selain diimplementasikan dalam pasalpasal Undang-undang Pangan, politik hukum ketahanan pangan nasional juga dapat didentifikasi, disimak, dan dikaji dari penjelasan Undang-undang Pangan. Di sini dikemukakan bahwa, Pembangunan nasional merupakan pencerminan kehendak untuk terusmenerus meningkatkan kemakmuran dan kesejahteraan rakyat Indonesia secara adil dan merata dalam segala aspek kehidupan serta diselenggarakan secara terpadu, terarah, dan berkesinambungan dalam rangka mewujudkan suatu masyarakat yang adil dan makmur, baik material maupun spiritual, berdasarkan Pancasila dan Undang-Undang Dasar 1945.

Pangan sebagai kebutuhan dasar manusia yang pemenuhannya merupakan hak asasi setiap rakyat Indonesia harus senantiasa tersedia cukup setiap waktu, aman, bermutu, bergizi, dan beragam dengan harga yang terjangkau oleh daya beli masyarakat. Untuk mencapai semua itu, perlu diselenggarakan suatu sistem pangan yang memberikan perlindungan, baik bagi pihak yang memproduksi maupun yang mengkonsumsi pangan, serta tidak bertentangan dengan keyakinan masyarakat. Sealian itu, sumber daya manusia yang berkualitas selain merupakan unsur terpenting yang perlu memperoleh prioritas dalam pembangunan, juga sebagai salah satu faktor penentu keberhasilan pembangunan. Peningkatan kualitas sumber daya manusia sangat ditentukan, antara lain, oleh kualitas pangan yang dikonsumsinya.

Kegiatan atau proses produksi pangan untuk diedarkan atau diperdagangkan harus memenuhi ketentuan tentang sanitasi pangan, bahan tambahan pangan, residu cemaran, dan kemasan pangan. Hal lain yang patut diperhatikan oleh setiap orang yang memproduksi pangan merupakan penggunaan 
metode tertentu dalam kegiatan atau proses produksi pangan yang memiliki kemungkinan timbulnya risiko yang dapat merugikan atau membahayakan kesehatan manusia, seperti rekayasa genetika atau iradiasi, harus dilakukan berdasarkan persyaratan tertentu. Setiap orang yang memproduksi pangan untuk diperdagangkan perlu memperhatikan ketentuan mengenai mutu dan gizi pangan yang ditetapkan. Pangan tertentu yang diperdagangkan dapat diwajibkan untuk terlebih dahulu diperiksa di laboratorium sebelum diedarkan. Dalam upaya meningkatkan kandungan gizi pangan olahan tertentu, Pemerintah berwenang untuk menetapkan persyaratan tentang komposisi pangan tersebut. Setiap orang yang memproduksi pangan untuk diedarkan perlu dibebani tanggung jawab, terutama apabila pangan yang diproduksinya menyebabkan baik kerugian pada kesehatan manusia maupun kematian orang yang mengkonsumsi pangan tersebut.

Ketentuan mengenai keamanan, mutu, dan gizi pangan, serta label dan iklanpangan tidak hanya berlaku bagi pangan yang diproduksi dan atau diedarkan di wilayah Indonesia, tetapi juga bagi pangan yang dimasukkan ke dalam wilayah Indonesia. Dalam hal-hal tertentu bagi produksi pangan nasional yang akan diedarkan di luar negeri, diberlakukan ketentuan yang sama. Sebagai komoditas dagang, pangan memiliki peranan yang sangat besar dalam peningkatan citra pangan nasional di dunia internasional dan sekaligus penghasil devisa. Oleh karena itu, produksi pangan nasional harus mampu memenuhi standar yang berlaku secara internasional dan memerlukan dukungan perdagangan pangan yang dapat memberi peluang bagi pengusaha di bidang pangan, baik yang besar, menengah maupun kecil, untuk mendukung pertumbuhan ekonomi.

Pengaturan mengenai pangan diarahkan untuk mewujudkan ketahanan pangan yang mencakup ketersediaan dan cadangan pangan, serta terjangkau sesuai dengan kebutuhan konsumsi masyarakat. Pemerintah bersama masyarakat perlu memelihara cadangan pangan nasional. Di samping itu, Pemerintah dapat mengendalikan harga pangan tertentu, baik untuk tujuan stabilisasi harga maupun untuk mengatasi keadaan apabila terjadi kekurangan pangan atau keadaan darurat lainnya. Undang-undang tentang Pangan dimaksudkan sebagai landasan hukum bagi pengaturan, pembinaan, dan pengawasan terhadap kegiatan atau proses produksi, peredaran, dan atau perdagangan pangan. Sebagai landasan hukum di bidang pangan, Undang-undang ini dimaksudkan menjadi acuan dari berbagai peraturan perundangundangan yang berkaitan dengan pangan, baik yang sudah ada maupun yang akan dibentuk.

Berdasarkan pemikiran-pemikiran sebagaimana yang diuraikan, Undang-undang tentang Pangan memuat pokok-pokok pengaturan:

a. Persyaratan teknis tentang pangan, yang meliputi ketentuan keamanan pangan, ketentuan mutu dan gizi pangan, serta ketentuan label dan iklan pangan, sebagai suatu sistem standarisasi pangan yang bersifat menyeluruh;

b. Tanggung jawab setiap orang yang memproduksi, menyimpan, mengangkut, dan atau mengedarkan pangan, serta sanksi hukum yang sesuai agar mendorong pemenuhan atas ketentuanketentuan yang ditetapkan;

c. Peranan Pemerintah dan masyarakat dalam mewujudkan tingkat kecukupan pangan di dalam negeri dan penganekaragaman pangan yang dikonsumsi secara tidak bertentangan dengan keyakinan masyarakat;

d. Tugas Pemerintah untuk membina serta mengembangkan industri pangan nasional, terutama dalam upaya peningkatan citra pangan nasional dan ekspor.

Pengaturan, pembinaan, dan atau pengawasan terhadap kegiatan atau proses produksi, peredaran, dan atau perdagangan pangan dalam Undangundang Pangan bersifat pokok-pokok, sedangkan penjabarannya lebih lanjut ditetapkan oleh Pemerintah secara menyeluruh dan terkoordinasi. Semuanya itu diselenggarakan dengan tetap memperhatikan kesiapan dan kebutuhan sistem pangan nasional, serta perkembangan yang terjadi baik secara regional maupun internasional.

\section{Simpulan}

Dari kajian yang telah dipaparkan dapat disimpulkan bahwa taraf sinkronisasi horizontal antara UU PVT dengan UU Pangan telah sinkron dan harmonis. UU PVT memberikan pengaturan pemberian dan perlindungan Hak PVT agar tercipta kegairahan para pemulia tanaman untuk 
menghasilkan bibit unggul tanaman, termasuk tanaman pangan, yang akan mampu meningkatkan produktivitas tanaman pangan sehingga ketercukupan bahan pangan sampai ke tingkat rumah tangga dapat terjamin. Hanya saja masih terjadi masalah, yaitu kurang harmonisnya pengaturan soal koordinasi dalam hal sosialisasi Hak PVT. Akibatnya masyarakat yang kurang mengetahui Hak PVT sering menjadi korban dari pihak-pihak yang tidak bertanggung jawab, antara lain kriminalisasi ketika masyarakat menggunakan hasil panennya sebagai bibit.

\section{E. Saran}

Saat ini sedang terjadi proses evaluasi UU PVT. Secara normatif yang perlu dilakukan adalah pengaturan mengenai sosialisasi dan peningkatan kesadaran hukum HKI dam hal ini perlindungan Hak PVT. Selain itu disarankan untuk lebih menegaskan bahwa pengaturan Hak PVT dengan segala perlindungan dan penghargaannya lebih diarahkan pada upaya-upaya pemuliaan tanaman yang menghasilkan bibit-bibit unggul tanaman pangan, tanpa mengabaikan pemuliaan tanaman yang mempunyai nilai ekonomis tinggi. 


\section{Daftar Pustaka}

Ade Ruskandar. 2012. "Adopsi Varietas Unggul Baru Padi dan Teknologi Budidaya di Tingkat Petani (kasus di Kalimantan Barat)". Prosiding Seminar Nasional, Surakarta: Fakultas Pertanian UNS, April 2012.

Badan Pusat Statistik (BPS). 2008, 2011. Data Tanaman Pangan. Jakarta: BPS (www.bps.go.id)

E.S. Beranang. 2012. "Jagungku Pendukung Kemandirian Pangan di Flores Timur". Prosiding Seminar Nasional, Surakarta : Fakultas Pertanian UNS, April 2012.

Emi Widayanti. 2012. "Kearifan Lokal Masyarakat Petani dalam Mewujudkan Ketahanan Pangan Rumah Tangga". Prosiding SeminarNasional, Surakarta: Fakultas Pertanian UNS, April 2012.

Imam Syaukani dan A. Ahsin Tohari. 2007. Dasar-dasar Politik Hukum. Jakarta: Raja Grafindo Persada. Kementerian Pertanian 2011. "Review 10 tahun Undang-Undang PVT". www.deptan.go.id (diakses tanggal 6 Oktober 2011).

Moch Najib Imanullah. 2012. "Hak PVT sebagai Instrumen Membangun Negara Agraris Yang Berkeadilan dan Berbasis Kearifan Lokal Menuju Ketahanan Pangan Nasional". Prosiding Seminar Nasional, Surakarta: Fakultas Pertanian UNS, April 2012.

Moh. Mahfud MD. 2006. Politik Hukum di Indonesia. Jakarta: LP3ES Satjipto Rahardjo. 1991. Ilmu Hukum. Bandung: Citra Aditya Bakti.

Soerjono Soekanto dan Sri Mamudji. 2007. Penelitian Hukum Normatif. Jakarta: Rajawali Pers.

Yudi Widodo. 2012. "Ubi-ubian dalam Wanatani: Sumbangsih Kearifan Lokal guna Mewujudkan Kedaulatan Pangan Seiring Tuntutan Global". Prosiding Seminar Nasional, Surakarta: Fakultas Pertanian UNS, April 2012. 